\title{
Ethnologies
}

\section{Consuming the Reality TV Wedding}

\section{Renee Sgroi}

Volume 28, numéro 2, 2006

\section{Les noces en vrai}

Wedding Realities

URI : https://id.erudit.org/iderudit/014985ar

DOI : https://doi.org/10.7202/014985ar

Aller au sommaire du numéro

\section{Éditeur(s)}

Association Canadienne d'Ethnologie et de Folklore

ISSN

1481-5974 (imprimé)

1708-0401 (numérique)

Découvrir la revue

Citer cet article

Sgroi, R. (2006). Consuming the Reality TV Wedding. Ethnologies, 28(2),

113-131. https://doi.org/10.7202/014985ar

\section{Résumé de l'article}

Cet article enquête au carrefour des noces, de l'industrie du mariage, de la consommation et de la télé-réalité en considérant l'émission de télé-réalité Trista and Ryan's Wedding. Cette émission montrait le mariage réel de Trista Rehn et Ryan Sutter, qui s'étaient rencontrés lors du tournage de The Bachelorette. L'auteure soutient que l'emphase mise par la télé-réalité sur le "réel ", ses techniques narratives (y compris l'association à des biens de consommation) et le fait que l'industrie du mariage pousse à ce que l'on ait des noces « uniques » convergent dans cette émission pour mobiliser les visions et les rêves que suscite le mariage en blanc traditionnel afin d'attirer les consommateurs vers des biens de consommation spécifiques. Elle en conclut que l'étude des noces dans la culture nord-américaine doit prendre en compte non seulement les pratiques et les rituels mis en oeuvre dans ces évènements sociaux et culturels, mais aussi considérer les manières par lesquelles des formes culturelles populaires comme la télé-réalité travaillent à produire des types particuliers d'images.
Ce document est protégé par la loi sur le droit d'auteur. L'utilisation des services d’Érudit (y compris la reproduction) est assujettie à sa politique d'utilisation que vous pouvez consulter en ligne.

https://apropos.erudit.org/fr/usagers/politique-dutilisation/ 


\title{
Consuming the Reality TV WedDing
}

\author{
Renee Sgroi \\ McMaster University, Hamilton
}

Weddings have become an expanding business in recent years. According to the American weddings statistics site, Association for Wedding Professionals International (AFWPI.com), ${ }^{1}$ the US wedding market was projected to reach $\$ 30$ billion in 2005 (cited in Schiering 2005: 18). A recent report entitled "The U.S. Marriage Market" by Packaged Facts ${ }^{2}$ reveals that weddings offer a potential gold mine to manufacturers and retailers (2002: 11). Weddings have become big business, a point that Chrys Ingraham clearly evidences in her study of the "wedding-industrial complex" (1999: 26). This complex includes wedding dress manufacturers, popular movies, the travel industry, diamond excavations, even chewing gum manufacturers and a whole host of other industries seemingly unrelated to the ideological associations conjured up by images of weddings. The complex operates to capitalize on the richness and bounty of associating with weddings and wedding imagery.

1. A few Canadian websites such as www.ebrides.com and www. canadianbride.com offer directories of Canadian bridal boutiques, photographers, and so on, but they are directed towards helping brides and would-be brides find wedding retailers and services within their areas. By contrast, AFWPI offers industry-related information for wedding retailers and manufacturers. The only Canadian wedding associations I was able to locate are the Wedding Photojournalists Association and the Brockville and Area Bridal Association (the latter provides listings about bridal shops and services pertaining to a specific region of Ontario).

2. Packaged Facts conducts market research for MarketResearch.com, and their report on the wedding market details spending patterns for engaged and newlywed couples as consumers of household products (see The U.S. Marriage Market 2002). 
Weddings make good business sense because they "serve capitalism by helping to create an industry based on women's fantasies of status and security built around marriage, symbolized in the wedding as a consumption practice" (Brown 1994: 57). As rituals, ceremonies, and social practices, weddings hold a special place within North American culture. Indeed, as Kristin Harris Walsh correctly asserts, "the image of the white wedding is one with which we are intimately acquainted," thus weddings provide ample room to manufacture consumer desires (2005: 239).

Those bridal desires and reveries have often been summoned in part through their representations within popular culture. Soap operas, for instance, help to produce wedding fantasies — the weddings of crucial characters not only advance plot lines but also focus viewer attention through their elaborate costumes, sets, and locations. Popular films such as Runaway Bride, Four Weddings and a Funeral, Wedding Crashers, My Big Fat Greek Wedding, "chick lit" novels such as Wedding Season, Something Borrowed, wedding magazines, and other mass cultural forms also work to generate bridal desires by displaying the successful wedding as the culmination of women's life experiences. More recently, reality TV formats also mine the widespread fields of bridal fantasy. Indeed, like soap operas and romance novels, reality TV is imbricated within what might be referred to as a "wedding imaginary."

Looking for Love: Bachelorettes in Alaska for instance, featured five single women looking for marriageable men in Alaska. Married by America focused on five singles who were matched up with a "fiancé(e)" chosen by the studio and TV audiences. Although perhaps somewhat less explicit in their marketing of marriage itself than these shows, other reality TV programmes also included marriageable relationships, often in which couples proposed to one another at the end of the series. For

3. See Brown (1994), Flitterman-Lewis (1988), and Radway (1991) for detailed discussions of weddings in soaps and romance novels. Chrys Ingraham uses the term "heterosexual imaginary" (1999: 15-16) to refer to the ensemble of stories, films, programmes, and aspects of popular culture that work to produce a desire for heterosexual romance and thus to reproduce heterosexuality as a norm within North American culture. Wilding (2003) also posits a "romantic" cultural logic at work within popular culture and society. By referring to a "wedding imaginary," I build on these notions of heterosexual imaginary and romantic cultural logic to include all spaces within popular culture centred on weddings. 
instance, Mr. Personality, Temptation Island, and The Bachelor and The Bachelorette series focus on the formation and breakup of marriageable couples, with proposals occurring on all of these shows at one point or another. Yet perhaps the most iconic example of weddings on reality TV occurred with the actual televised wedding in 2003 of reality TV stars Trista Rehn and Ryan Sutter, who met while dating on The Bachelorette.

Trista and Ryan's Wedding was a three-part reality TV series that aired in November and December 2003. It was the culmination of a telegenerated love story that began when Trista Rehn met Ryan Sutter on the first series of ABC's The Bachelorette. Trista dated 25 men, eliminating them all to finally choose firefighter Ryan Sutter as her potential mate. The Bachelorette ended when Trista and Ryan mutually proposed to one another. The wedding, and the series that documents it, followed about one year later. The show, not coincidentally, aired during the November/December sweeps week and garnered some 17 million US viewers on the night of the wedding.

Strictly speaking, Trista and Ryan's Wedding is not the first reality TV programme to feature a real-life wedding. As both Jennifer Maher and Rebecca Stephens point out, shows such as A Wedding Story and A Baby Story have entranced viewers with fantasies of heterosexual love, marriage and the baby carriage for a few years. Maher argues that $A$ Wedding Story and A Baby Story work to soothe women's dissatisfaction with heterosexuality by offering escapist fantasies that nonetheless prove that "dreams can come true" (2004: 199). In other words, the real-life wedding and birth stories played out on these TLC (The Learning Channel) shows offer viewers a vision of a "fantasy" world that is, in fact, possible within the diegesis of the reality programme. Like these shows, Trista and Ryan's Wedding also enables a space to view a wedding fantasy come to life.

Yet one of the key differences between these shows is the fact that the TLC shows air during the day, while Trista and Ryan's Wedding, like The Bachelorette series from which it originated, air at night. Prime time and daytime reflect crucial programming differences, related particularly to the size and range of their demographics. Maher indicates that she herself fits within the targeted demographic of daytime programmes such as A Wedding Story: 
(eighteen to thirty-four and female), and I enjoy popular documentary television... I have baby fever... I read fashion magazines on occasion, abuse hair dye, and sometimes shop in the juniors department. I have been known to listen to mindless pop music (2004: 197).

In contrast, the target audience for Trista and Ryan's Wedding includes and extends beyond Maher's demographic. Prime time implies a wealthier and more diverse audience. Byars and Meehan argue that "women's television now figures in primetime" because women who work outside the home may have more spending power than their stayat-home sisters (2000: 148-149). As a result, these scholars indicate that over the years, prime-time television changed to attract "females with considerable disposable income who maintained control over that income" (149). As a prime time show that aired at eight p.m., Trista and Ryan's Wedding functions in part to attract this potentially lucrative audience market. Indeed, the show's inclusion during "sweeps week," in which networks aim for high ratings numbers, further supports the point that Trista and Ryan's Wedding was intended to attract a range of audiences/consumers. Thus, while Trista and Ryan's Wedding may not have been the first real-life wedding to air on a reality TV programme, its distinct location in prime time makes this show valuable to interrogate because of its relationship to a broad audience market and their consumption practices/desires.

According to Mark Andrejevic, reality TV is linked to consumption because by inviting viewers to become comfortable with forms of surveillance, it encourages them to occupy the position of consumer/ producer. In other words, "ordinary" people participate on and contribute to reality shows, both as contestants and as audience members who vote online or via text messages. Andrejevic views this participation as "audience labour" (2002: 256), and he compares it to the work consumers must do in the current era of mass customization, in which products are mass produced yet simultaneously customized to individual needs and preferences. The contradiction inherent in the term "mass customization" occurs when individuals tailor products through online ordering services (for instance, many websites allow you to "build" your own car or computer, and to subsequently purchase the individualized product you have produced), and when businesses target consumers based on individual profiles. Mass customization depends on consumer surveillance and intense market research and 
actually requires that consumers perform a certain amount of the surplus labour required for the mechanisms of capitalism to function. Thus "consumer labor is a source of profit, both directly as a means of adding value to a particular customized product, and indirectly when information generated by consumers is aggregated and sold as a commodity in its own right" (257). Building a car or a computer online then allows manufacturers and retailers to gather information about consumer preferences, aggregating them into a database, and then targeting consumers based on this information.

By comparing consumer labour to audience labor, Andrejevic argues that "a television show such as 'The Real World'... serves as a form of acclimatization to an emerging economic regime predicated on increasingly unequal access to, and control over, information" (267). He claims that this acclimatization is accomplished in the way that reality TV uses surveillance and voyeurism to naturalize what he refers to as the "work of being watched" (2004). Andrejevic's argument theorizes reality TV less for its entertainment value and more as a means to capitalize (pun intended) on viewers as shoppers. This function is especially pertinent given that Trista and Ryan's Wedding was a primetime show, and thereby potentially attracted viewers with increased spending power.

Building upon Andrejevic's claims, I examine how reality TV might encourage online commerce and the surplus labour it depends upon, less via acclimatization than through actual consumption practices. I propose that the consumption practices naturalized through the forms of surveillance and control engendered by reality TV are inextricably linked here to the wedding imaginary. If reality TV encourages surplus audience labour, how and where is that labour encouraged and produced? How does Trista and Ryan's Wedding operationalize the wedding imaginary and its existing links to consumption?

Ostensibly, the answer lies in the show's emphasis and glorification of consumption and shopping. From designer bridal shoes to gowns to personalized wedding invitations and china patterns, the wedding idealizes consumption. The glue binding the wedding to commerce is narrative. Narrative is a key feature of televisual texts. Although reality TV is premised upon its ability to present "the real" and "the actual," in practice, such programmes rely on narratives to structure the shots and 
episodes. Its narratives provide reality TV shows with the possibilities for meaningful reception (Hill 2005; Kavka and West 2004). Reality TV narratives, according to Anita Biressi and Heather Nunn, are significant because "there is a perception among some viewers that television, especially non-fiction television, should 'tell it like it is"' (2005: 3). They argue that reality TV "raises the ante" so that it "lays claim to reveal social, psychological, political and historical truths and to depict the rhythms and structures of everyday life with the least recourse possible to dramatisation and artifice" (3).

Narrative thus offers a door for viewers to evaluate the "reality" of a given programme. As Justin Lewis points out, viewers scrutinize reality TV shows based on two epistemological contradictions: "the more tactile reality of our immediate environment and the more symbolic reality of the world beyond it" (2004: 297). Using these two "realities," in Lewis' terms, viewers make sense and assess the authenticity of the reality TV shows they watch. However, by scrutinizing and closely evaluating the believability of the narrative, viewers also engage with questions of authenticity and, in this case, with the wedding imaginary and the representation of consumption on Trista and Ryan's Wedding.

Narrative comprises not only the story — the chronological events and some notion of the causal links between them - but also its discourse - how the story is expressed and presented (Chatman 1978; Kozloff 1992). I am particularly concerned with discourse, since presentation implicates how a narrative is structured. How the story is told, and which elements are valued over others within the narrative, indicates the lessons directed to audiences watching Trista and Ryan's Wedding. Reality TV's ability to "teach" stems in part from its roots in documentary. The documentary genre instructs because it attempts to reveal "truth." 4 Both the direct cinema tradition in the United States (in which the viewer and the filmmaker are positioned like a fly on the wall, little or no film crew intervention is seen, and viewers are supposed to make up their own minds about the subject matter [Dovey 2000]),

4. Even the contrived documentary Nanook of the North was originally viewed as offering a form of cultural pedagogy. The narrative technique of focusing on a single Inuit family in this 1922 documentary film made for a popular and compelling tale, yet director Robert J. Flaherty compromised realism for entertainment. As Louis Menand details, among other constructed scenarios, Flaherty staged a walrus hunt, even though this Inuit practice had long ceased to be common (2004: 90). Thus, although this film is one of the earliest forms of powerful documentary filmmaking, its credibility in the genre is suspect. 
and the cinéma vérité tradition in Europe (in which the director is inserted into the film, assuming viewers cannot possibly position themselves objectively [Barnfield 2002]) provide access to "the real" and "the truth" (Clissold 2004; McCarthy 2004; Pecora 2002). Although viewers are aware that reality TV's relationship to "truth" may be as contentious as documentary's, reality TV nevertheless retains a degree of verisimilitude in part because of its use of documentary techniques (Hill 2005).

Reality TV's pedagogical focus may also stem from its televisual prototype, Candid Camera. ${ }^{5}$ Candid Camera used hidden cameras that provided access to a "truth" or "truths" about human behavior (Clissold 2004; McCarthy 2004). These "truths" were therefore made available to audiences as social and pedagogical tools. Indeed, Allen Funt, the show's creator and host, thought of the hidden camera's impact in "therapeutic terms," as a means to help people "learn from their mistakes" (quoted in McCarthy 2004: 26). Thus, "Candid Camera and Omnibus [a programme which aired mostly documentaries, but upon which Funt's early work appeared] sought to both educate and entertain" (27). The show was conceptualized and functioned, in part, as a kind of pedagogical or instructive tool.

As Trista and Ryan's Wedding promotes the heterosexual fantasy of romantic love and marriage, it also offers lessons around consumption. While Trista and Ryan's Wedding may not "train" viewers to become online shoppers as Andrejevic (2002) might argue, it does teach them about how they too might be able to reproduce the fantasy of heterosexual love and romance in their own weddings. These pedagogical moments emerge in the show's narrative, which is broken into a three-part structure. Episode one functions as the exposition; episode two introduces conflict via the possible temptations presented by the bachelor and bachelorette parties; ${ }^{6}$ and episode three is the

5. Some critics and researchers, including Brenton and Cohen (2003), Caldwell (2002), Kraszewski (2004) and Tincknell and Raghuram (2004) also point to MTV's The Real World as a prototype because it was one of the first late-century shows to feature a group of strangers living together in a contrived environment, trying to win money. While The Real World may have influenced later shows, it is perhaps less significant as a prototype than Candid Camera because the MTV show borrows the same kinds of techniques, especially in terms of the use of cameras for surveillance, that Candid Camera made famous.

6. See Sgroi (2005) for a description of the importance of temptation within the narrative structure of romance-based reality TV shows such as The Bachelorette and Trista and Ryan's Wedding. 
resolution. Episodes one and three of Trista and Ryan's Wedding offer the clearest examples of consumption at work. No less than twelve sequences centre on consumption in the first episode of the show, and it is worthwhile to consider each one briefly in order to demonstrate the scope of consumption.

First, Trista visits with wedding planner Mindy Weiss. Weiss, Trista tells viewers, has planned weddings for celebrities including Adam Sandler and Gwen Stefani. Next, Trista, Ryan, and Weiss visit florist Mark's Garden, where they see tables decorated with elaborate floral arrangements, and discuss their plans for the wedding. They then make their way to Lenox, where Trista and Ryan meet with a designer to have their own personalized china designed. At Lair and Black, Trista and Ryan are shown examples of specialized engagement and wedding invitations created for them. One example features a paper "closet," in which hangs a pink paper bridal gown with Trista's name on it, and a black paper tuxedo with Ryan's. After Lair and Black, Trista and Ryan are seen at Perfect Endings, where they sample various decadent cakes. Following the cake tasting, the couple meets with a designer at Tacori, the jewellery makers, where they will plan their own wedding bands. In the next sequence, Trista and Ryan, along with Weiss, examine the Villa at Rancho Lodge, where the wedding and reception will occur. Here, Weiss and Trista practice walking down the aisle, as Ryan waits across the lawn in front of a gazebo. Next, Trista and her mother visit designer studio Badgely Mischka. The two are treated to a fashion show of bridal gowns, as they discuss the possibilities for Trista's own dress. At Amsale, Trista and her bridesmaids choose the bridesmaid dresses, while the men try on tuxedos at Kenneth Cole. The shopping sequences concluded, the episode moves on to focus on Trista and Ryan's party in New York where they invite their friends and family to participate in the wedding. Yet the episode ends with one final shopping sequence, where Trista and Ryan invest in dance lessons from the "Dance Doctor," in preparation for their wedding. Taken together, the insistent focus on consumption in these sequences illustrates consumerism's centrality within the wedding imaginary.

One significant aspect in these shopping sequences is the display of celebrity spectacle, and how Trista and Ryan are given the star treatment. Celebrity spectacle matters because, as Ingraham writes, celebrities "become the vehicles through which the masses not only imagine the 
possibility of wealth and fame but seek to emulate it as well, thereby legimitating the accumulation practices of the rich and famous" (1999: 108). By positioning Trista and Ryan as "stars," the show's narrative sets them up as models to be emulated by would-be brides and grooms in the viewing audience. In order to occupy these starring roles, Trista and Ryan must be treated like celebrities - partly accomplished by having Weiss as their celebrity wedding planner.

Weiss's presence, and her positioning as a noted celebrity wedding planner, functions to put the spectacle of the wedding in motion for viewers. Weiss herself admits on the show: "I was really excited to meet Trista. The moment Ryan proposed to her, I said 'uh, I would love to do that wedding.' So to have the opportunity, I feel very lucky" (episode one). Weiss's participation lends exclusivity and status to this affair; she is also the person who introduces Trista and Ryan (and by extension, the viewing audience) to the many famous designers involved in the wedding. For example, to introduce Trista's visit to the wedding's shoe designer, Weiss informs us: "Stuart Weitzman is one of the best shoe designers in the country. He's best known for the shoes that he designed for the Academy Awards that were worth one million dollars" (episode one). Weitzman's fame is directly tied here to the expense of the designer shoes that he has created. Similarly, Weiss describes Mark, of Mark's Garden, as a most spectacular florist. She says: "I know Mark is going to do a phenomenal job. He's been part of the most lavish celebrity weddings. Charlie Sheen and Denise Richards, Adam Sandler" (episode one). At each stop that they make along the bridal consumption route, Weiss is there to inform viewers about the costliness and the extravagance of the purchases made for Trista and Ryan's wedding.

Weiss's role in the wedding is also significant because she is the expert. Without going into detail about the role of the expert on reality $\mathrm{TV},{ }^{7}$ suffice it to say that the expert's knowledge (which is usually male) works to assist the star of the show. Weiss's role as expert thus usurps Chris Harrison's role as host because she possesses the more relevant knowledge about shopping. The expert's knowledge becomes part of the instructional content of the narrative and provides viewers a means to be "in the know" about designers and brands.

7. See Sgroi (2006) for a discussion of the role of the male expert on Joe Millionaire, and The Bachelor and The Bachelorette series. 
Weiss's expert knowledge also signals the wedding's "unique" status. As host Harrison ${ }^{8}$ states at the start of episode three: "Obviously, this is no ordinary wedding." He goes on to assert that: "Tonight's wedding is unique, because of all the reality shows around the world, this is the first to result in a real marriage" (episode three). Trista and Ryan's wedding is bracketed as different, anything but ordinary, and yet simultaneously real. As Weiss tells Harrison at the start of this episode: "I've never been involved in anything like this. When the brides come in and interview me, the first thing I say is: 'This will not be a production.' So I'm trying to keep it feeling intimate, so Trista and Ryan really feel that they have a wedding planner, their guests are here, and the cameras are secondary" (episode three, emphasis original).

The wedding's uniqueness is very much tied to consumption choices. The practice of expressing oneself through individual choices in the market has long been a integral to bourgeois ideology. In her interviews with engaged and recently married couples, for instance, Dawn Currie found that "both the amount of planning and expense [in the weddings of her interviewees] were the results of paying attention to details which, although often seen as 'not really necessary,' were important to respondents" (1993: 407). These minute details apparently allowed the interviewees to express their personalities, a notion that Currie indicates is spelled out in bridal magazines. The idea of a personalized wedding occurred in several of Currie's discussions with respondents (417). She argues that the personalized weddings are significant "because commodification and mass consumption act to standardize products, [and thus] a personalized wedding can only be achieved through giving attention to a myriad of individual details" (417). Their "unique" wedding allows Trista and Ryan, like the interviewees in Currie's study, to express their individual good taste. Indeed, as Weiss comments in episode three, "It's all the little touches that are going to make this wedding extra special" (emphasis original). Personalizing the wedding and purchasing those "little touches" adds value to Trista and Ryan's wedding.

So, for instance, with regard to Trista and Ryan's visit to Lenox, Weiss says: "The next stop for Ryan and Trista is Lenox, where they're going to be picking out china for their reception. This is such an amazing opportunity for them. They get to design china from the same place

8. Harrison is also host of the The Bachelor and The Bachelorette series. 
that designs for the White House and Royal Family" (episode one). Similarly, when the couple visits Tacori, the jewelry designers, Weiss states: "One of the most important things for Trista and Ryan is choosing the rings. Tacori's rings are hand-crafted. So Trista and Ryan are going to be the only ones that have that designed rings [sic] just for them" (emphasis original, episode one). And, in case Trista and Ryan's wedding was not unique enough, at Trista's visit to Stuart Weitzman's shop, viewers learn from Weitzman himself that Trista will have "the most expensive bridal shoe [sic] ever made in the history of the world, the most valuable" (episode one).

Critical to these products' uniqueness and the way that Trista and Ryan shop for them is the manner in which they work to represent and actualize, to some degree, individual choice. Paul du Gay outlines the place of individuals within a culture of enterprise in late capitalism, in which they must become "entrepreneurs" of their lives.

\begin{abstract}
Autonomous, self-regulating and self-actualizing individual actors seeking to maximize their "quality of life" — in other words, to optimize the worth of their existence to themselves - [do so] by assembling a lifestyle, or lifestyles, through personalized acts of choice in the market place. Thus, in enterprise culture, freedom and independence emanate not from civil rights but from individual choices exercised in the market (1996: 77).
\end{abstract}

Shopping and retailing are important, then, because once all manner of action and thought can be modeled on the market (which is one effect of enterprise culture), all can be reduced to a retailing or shopping logic. The products Trista and Ryan choose, and the ways in which these products are personalized to their specifications, suggests that the choices they make for the wedding are significant because these choices speak to the couple's identities and individualism. Thus, whether or not viewers wish - or have the economic means - to emulate Trista and Ryan's Wedding perhaps matters less than the central point made through the attention to minute details: that individuality, taste, personality, and identity are expressed as a function of consumer choice.

A key sequence in episode three makes this point explicitly. Host Harrison begins this sequence by stating that: "Any father planning to give his daughter a wedding like this better have deep pockets because Trista's fantasy wedding didn't come cheap." Harrison then goes on to 
tally the cost of the wedding for viewers, with the tally sutured to shots of the expensive items discussed. The cost of the wedding included: $\$ 250,000$ on wardrobe which includes $\$ 100,000$ for Trista's wedding gowns, ${ }^{9} \$ 155,000$ for food and drink, $\$ 15,000$ for the cake, $\$ 500,000$ for the flowers (featuring 60,000 long-stemmed roses), $\$ 105,000$ for the live music, $\$ 30,000$ for gift bags, $\$ 83,000$ for the custom-made invitations, $\$ 750,000$ for the location, $\$ 1,250,000$ for jewelry, and $\$ 63,000$ for linens. The grand total of the wedding is $\$ 3,778,000$. A "ka-ching" cash register sounds as Harrison reveals the total, and the numbers flash up on the screen.

While the reality TV wedding here may appear to be a real-life manifestation of a fairytale romance, the show's narrative itself acknowledges its own spectacle and expense, thereby signaling this fairytale's inaccessibility to most viewers. At the same time, however, the contradiction raised by the narrative's own identification of the bridal expenses speaks to the importance of the wedding imaginary's functioning as an instructional tool that teaches viewers how to emulate and learn from this reality TV wedding.

In fact, if consumption is central to Trista and Ryan's Wedding, then it may also be relevant, if not central, to viewers. As Ingraham suggests, the celebrity wedding spectacle mobilizes viewer desires at the same time as it offers a vision of a wedding that they can emulate. An article in Elegant Bride indicates that viewers did try to emulate aspects of this "real" wedding: "Opulent weddings on television can also send brides on a shopping spree. One planner reports that scores of young women wanted the 'dripping roses' shown in the prime-time nuptials of The Bachelorette couple Trista Rehn and Ryan Sutter" ("Due Diligence"). While the designer shoes and china are far beyond the means of most television viewers, Trista and Ryan's Wedding nevertheless mobilizes desires about particular objects and displays, and inspires the wedding imaginary.

As Andrejevic argues, then, reality TV possesses the potential to blend the spectator position into that of viewer/consumer, so that audiences may not only see dripping roses, but want to purchase them as well. Kim B. Sheehan and Aibing Guo's research on TV advertising

9. Trista wore a more traditional "Cinderella" gown to the ceremony, and a more contemporary evening gown to the reception so that, in her words, she could dance. 
further supports the links between reality TV viewing and consumption. Their work suggests that reality TV narratives enable a fusion of story and advertising that, I propose, helps to cement the emphasis on consumption. Sheehan and Guo argue that the idea of product placement in film and television, whereby advertisers ensure that their products are made visible in a scene, has moved to a new level with reality TV. In this new scenario, products become assimilated within narratives, and Sheehan and Guo identify four levels of product assimilation.

The first "is when a brand name product or service is used as a 'prop' in a film or television show" (2005: 80). The second level, "enhanced product placement," occurs "when the product or service moves beyond serving as a prop in the storyline and becomes more connected with the storyline" (81). The third level is "product integration," in which the product becomes more central to the plot. For instance, they point to All My Children's incorporation of the cosmetics company Revlon as an employer characters worked with and struggled against in the soap's plots. Finally, "product assimilation is when the product becomes the plot" (82). Sheehan and Guo argue that "product assimilation is basically a reality show with the product as the star of the program" (82). The example they provide is the show Airline, which features Southwest Airlines and its employees, and the kinds of encounters they have with one another and with passengers.

The products and services on Trista and Ryan's Wedding can be situated between enhanced product placement and product integration, Sheehan and Guo's second and third levels of intensity. While the shoes, the dresses, the flowers are crucial to the spectacle created for the wedding, the show is ultimately about the wedding, and not about Stuart Weitzman Inc. or Kenneth Cole. Nevertheless, as suggested above, the products are critical to the narrative because the wedding is proverbially about "what the bride wore." In episode one, the products are described, but in episode three, they are revealed in close-up, behind-the-scenes shots. Because the products appear beyond the first episode, the products move beyond the space of enhanced product placement. Rather, I propose that the products' visibility in episode three positions them within the third level of Sheehan and Guo's categorization, so that they function as product integration. 
In episode three, viewers find a sequence that reintroduces the products and designers seen in episode one. This sequence brings back these items, and displays them for viewers in all their celebrity glamour. For instance, Harrison, the show's host, introduces the segment by indicating that "the real work began one week ago, when Weiss and her staff arrived at the wedding site and a crew of 100 workmen began transforming the Lodge to accommodate the ceremony, the reception and the rehearsal dinner" (episode three). Again, viewers see that Weiss is positioned as the expert and ringleader, orchestrating the wedding and overseeing minute details. Weiss then takes up Harrison's lead, and points out all the little details that make the wedding so special. Yet her comments are also sutured to several shots that work to tie in the products once again.

So, for example, Weiss tells viewers that: "2000 pieces of Lenox china, 5300 pieces of silverware, 3000 wine and champagne glasses have been shipped in just for the wedding reception." During this commentary, viewers see shots of the china, the silverware, and a shot of Weiss herself inspecting the glasses. Similarly, Harrison tells viewers about how the wedding gowns, shoes, and jewelry arrived in an armoured van (including an obligatory shot of the Brinks truck). A close up shows Trista's wedding shoes, lovingly displayed in a see-through glass box. Weiss then tells us: "Stuart Weitzman has designed Trista's one-of-akind wedding shoes," and this clip is followed by an interview with Weitzman himself. During it, Weitzman tells viewers that "there are about eight plus carats [on Trista's shoes]. I think there are more carats in this pair of shoes than in the wedding ring that Trista will be wearing" (episode three).

These sequences display the spectacle of the wedding, but they also potentially motivate desires around these specific products, since the merchandise itself has become central to what makes Trista and Ryan's wedding so special. Just as the divide between viewers and consumers is synthesized as viewers engage with and participate on reality TV, so too is the line between narrative and commerce erased. The wedding of these two "ordinary" people just would not be the same without the Stuart Weitzman shoes, the Tacori rings, and so on. The importance, then, of product placement within this show is that consumers (especially the "urban" market which "is characterized by rapidly increasing spending power" [Shrum 2003: 172] and depends more upon technology than the Boomer generation it follows) are 
becoming more accepting and less skeptical of products advertised through placement than through traditional methods of advertising. In addition, awareness and memory recall of advertisements appears to be enhanced by product placement (172). This process suggests that the centrality of the designer products displayed on Trista and Ryan's Wedding might produce greater viewer recall, with the ultimate potential of translating into sales.

Consuming the reality TV wedding becomes something more than simply watching a TV show about a wedding. Because of the intersection of narrative, pedagogy, and the significance of notions of "realness," uniqueness, and celebrity that converge within the space of the reality TV wedding, Trista and Ryan's Wedding offers a critical site to consider the image of the white wedding and the consumer desires it conjures up. While this show may utilize and build on strategies that are part and parcel of existing traditional North American wedding practices, Trista and Ryan's Wedding assumes a different cast because the wedding occurs within this space of the "real" where the products being consumed move beyond product placement to occupy more central positions within the show's narrative. Combined with the expert knowledge provided by Weiss, and the pedagogical lessons implicit in reality TV as a format, Trista and Ryan's Wedding thus mobilizes fantasies, dreams and images of the traditional white wedding, and it takes these reveries to new levels by integrally linking them with the story such that the fairytale would not be the same without Stuart Weitzman shoes, Amsale dresses, Tacori rings, and so on. Trista and Ryan's Wedding, much like A Wedding Story, offers soothing stories about heterosexuality, love, and marriage, and fantasies about spectacle and celebrity. Yet more importantly, it offers the space for viewing pleasures to be directed not only towards specific products and brand names, but to consumption in general. 


\section{References}

Andrejevic, Mark. 2002. "The Kinder, Gentler Gaze of Big Brother:

Reality TV in the Era of Digital Capitalism." New Media and Society 4 (2): 251-270.

Andrejevic, Mark. 2004. Reality TV: The Work of Being Watched. Lanham:

Rowman and Littlefield.

Barnfield, Graham. 2002. "From Direct Cinema to Car-Wreck Video:

Reality TV and the Crisis of Content." In Dolan Cummings ed.,

Reality TV: How Real is Real?: 47-66. London: Hodder \& Stoughton. Biressi, Anita and Heather Nunn 2005. Reality TV: Realism and

Revelation. London: Wallflower Press.

Brenton, Sam and Reuben Cohen 2003. Shooting People: Adventures in Reality TV. London and New York: Verso.

Brown, Mary Ellen. 1994. Soap Opera and Women's Talk: The Pleasure of Resistance. Thousand Oaks (CA): Sage Publications.

Byars, Jackie and Eileen R. Meehan. 2000. "Once in a Lifetime:

Constructing 'The Working Woman' through Cable

Narrowcasting." In Horace Newcomb ed., Television: The Critical

View: 144-168. Oxford: Oxford University Press.

Caldwell, John T. 2002. "Prime-Time Fiction Theorizes the Docu-Real." In John Friedman ed., Reality Squared: Televisual Discourse on the Real: 259-292. New Brunswick (NJ): Rutgers University Press.

Chatman, Seymour. 1978. Story and Discourse: Narrative Structure in Fiction and Film. London: Cornell University Press.

Clissold, Bradley D. 2004. "Candid Camera and the Origins of Reality TV: Contextualising a Historical Precedent." In Su Holmes and Deborah Jerymn eds., Understanding Reality Television: 33-53. London and New York: Routledge.

Cowan, Chris and Jean-Michel Michenaud, producers. 2003. Joe Millionaire. Television series. France/United States: Fox, January 6 to February 18.

- 2001. Temptation Island. Television series. United States: Fox, January 10 to February 22.

Currie, Dawn H. 1993. "Here Comes the Bride: the Making of a 'Modern Traditional' Wedding in Western Culture. Journal of Comparative Family Studies 24 (3): 403-421.

Dovey, Jon. 2000. Freakshow: First Person Media and Factual Television. London: Pluto Press.

du Gay, Paul. 1996. Consumption and Identity at Work. London: Sage Publications. 
"Due Diligence: Staying Blissfully on Budget is Easier than You Think." n.d. Elegant Bride. http://www.brides.com/planning/budget/feature/ article/7658?printable=true, retrieved April 26, 2006.

Fleiss, Mike, executive producer. 2003. The Bachelorette. Television series. United States: ABC, January 8 to February 20.

2003. Trista and Ryan's Wedding. Television series. United States: ABC, November 26 to December 10.

Flitterman-Lewis, Sally. 1988. "All's well that doesn't end: Soap Opera and the Marriage Motif." Camera Obscura 16 (January): 119-127. Haimes, T., Chris Cowan, and Jean-Michel Michenaud, executive producers. 2003. Married by America. Television series. United States: Fox, March 4 to April 16.

Harris Walsh, Kristin 2005. "You Just Nod and Pin and Sew and Let Them Do Their Thing:' An Analysis of the Wedding Dress as an Artifact and Signifier." Ethnologies 27 (2): 239-259.

Hill, Annette. 2005. Reality TV: Audiences and Popular Factual Television. New York: Routledge.

Ingraham, Chrys. 1999. White Weddings: Romancing Heterosexuality in Popular Culture. New York: Routledge.

Kavka, Misha and Amy West. 2004. "Temporalities of the real: Conceptualising time in Reality TV." In Su Holmes and Deborah Jerymn eds., Understanding Reality Television: 136-153. New York: Routledge.

Kilborn, Richard. 1994. "How real can you get? Recent developments in 'Reality' Television." European Journal of Communication 9: 42139.

Kozloff, Sarah. 1992 [1987]. "Narrative theory and television." In Richard Allen ed., Channels of Discourse, Reassembled: 67-100. Chapel Hill (NC): University of North Carolina Press.

Kraszewski, Jon. 2004. "Country hicks and urban cliques: Mediating race, reality, and Liberalism on MTV's The Real World." In Susan Murray and Laurie Ouellette eds., Reality TV: Remaking Television Culture: 179-196. New York: New York University Press.

Lewis, Justin. 2004. "The meaning of real life." In Susan Murray and Laurie Ouellette eds., Reality TV: Remaking television culture: 288302. New York: New York University Press.

Maher, Jennifer. 2004. "What do women watch? Tuning in to the compulsory heterosexuality channel." In Susan Murray and Laurie Ouellette eds., Reality TV: Remaking Television Culture: 197-213. New York: New York University Press. 
McCarthy, Anna. 2004. “'Stanley Milgram, Allen Funt, and Me:' Postwar social science and the 'First Wave' of Reality TV." In Susan Murray and Laurie Ouellette eds., Reality TV: Remaking Television Culture:19. 39. New York: New York University Press.

Menand, Louis. 2004. "Nanook and Me: Fahrenheit 9/11 and the Documentary Tradition." The New Yorker 80 (22): 90-96.

Nash, B. and Godinsky, B., executive producers. 2003 Mr. Personality. Television series. United States: Fox, April 23 to May 21.

Paolantonio, Bill, Messick, Scott, and Eric Schotz, executive producers. 2002. Looking for Love: Bachelorettes in Alaska. Television series. United States: Fox, June 10 to July 7.

Pecora, Vincent P. 2002. "The Culture of Surveillance." Qualitative Sociology 25 (3): 345-358.

Radway, Janice. 1991 [1984]. Reading the Romance: Women, Patriarchy, and Popular Literature. Chapel Hill: University of North Carolina Press.

Schiering, Matt. 2005. "Wedding Crash Course." Brandweek 46 (29): 18.

Sgroi, Renee. 2005. Love is On the Air: Gender, Pedagogy, and the Subject(s) of Romance Reality TV. Unpublished dissertation, University of Toronto, Toronto.

- 2006. "Joe Millionaire and Women's Positions: A Question of Class." Feminist Media Studies 6 (3): 281-295.

Sheehan, Kim B. and Aibing Guo. 2005. "Leaving on a (Branded) Jet Plane:' An Exploration of Audience Attitudes towards Product Assimilation in Television Content." Journal of Current Issues and Research in Advertising 27 (1): 79-91.

Shrum, L. J. 2003. "Where Art and Commerce Collide: A Funnel Approach to Embedding Messages in Non-Traditional Media." Advances in Consumer Research 30: 170-174.

Stephens, Rebecca L. 2004. "Socially soothing stories? Gender, race and class in TLC's A Wedding Story and A Baby Story. In Su Holmes and Deborah Jerymn eds., Understanding Reality Television: 191-210. New York: Routledge.

Tincknell, Estella and Parvati Raghuram. 2004. "Big Brother: Reconfiguring the 'active' audience of cultural studies?" In Susan Murray and Laurie Ouellette eds., Reality TV: Remaking Television Culture: 252-269. New York: Routledge. 
"The U.S. Marriage Market: The Engaged and Newlyweds as Consumers of Household Goods." 2002. http://www.marketresearch.com, retrieved April 28, 2006.

Wilding, Raelene. 2003. "Romantic love and 'getting married:' Narratives of the wedding in and out of cinema texts." Journal of Sociology 39 (4): 373-389. 